\title{
О.М. Колмакова
}

Харківський національний університет будівництва та архітектури, Украӥна

\section{ЕКОНОМІЧНА БЕЗПЕКА УКРАЇНИ: ЕНЕРГЕТИЧНИЙ АСПЕКТ}

Автором проведено детальний аналіз основних складових поняття «Економічна безпека держави». В дослідженні відстежено взаємозв'язок показників, щчо характеризують економічну безпеку держави, дано детальне описання основних складових економічної безпеки держави, проаналізована динаміка розвитку відновлюваних джерел енергії y світі. В результаті дослідження взаємозв'язку впровадження альтернативних джерел енергї та енергетичної безпеки України, доведено доцільність їх впровадження. Отримані регресійні моделі для прогнозування зв'язку між економічною безпекою та фінансовою, енергетичною складовими. Розроблені моделі в цілому статистично значимі. В результаті їх застосування автор отримав прогнозну динаміку рівня економічної безпеки Украӥни, щзо доводить: 3 постійним збільшенням інтегральних коефічієнтів енергетичної та фінансової безпеки інтегральний коефіцієнт економічної безпеки Украӥни буде знаходитися вище порогового значення.

Ключові слова: економічна безпека, енергетична безпека, альтернативні джерела енергії, прогнозування.

\section{Постановка проблеми}

Охорона навколишнього середовища може i має бути вигідною $з$ економічної точки зору. Економічні ефекти від впровадження альтернативних та відновлюваних джерел енергії (АДЕ та ВДЕ) не завжди можна визначити прямим розрахунком. Частіше вплив природоохоронних заходів та застосування екологічно чистих джерел енергії виявляється через певний час. В сучасному світі основним пріоритетом енергетичною галузі $€$ відновлюваність джерела енергії та його екологічність. Використання альтернативних джерел енергії дозволяє посилити економічну та енергетичну безпеки держави. Помірноконтинентальний клімат Україні обумовлює наявність опалюваного сезону, а відповідно потребу в енергії. Вартість кожного товару та послуги містить в собі вартість енергії. Відповідно енергетична політика держави безпосередньо впливають на соціально-економічний стан України. Що підтверджує актуальність теми дослідження.

\section{Аналіз останніх досліджень і публікацій}

Теоретичні й прикладні аспекти економічної безпеки висвітлені в роботах Л.С. Шевченко [1], О.А. Гриценко [1], О.А. Олейнікова [2], А.В. Хаванов [3], І.М. Вахович [5], О.С . Табалова [5], В.В. Смачило [6], О.М. Колмакова [6], Д.Д. Буркальцева [8], Ю.М. Харазішвілі [9], С.В. Дронь [9] та ін.

Проблеми впровадження АДЕ та ВДЕ досліджено в наукових працях С. Б. Воронцов [10],
А.А. Сидоренко [10], А.Ю. Сменковський [10] та iH.

Метою статті $\epsilon$ проаналізувати сучасний стан галузі АДЕ та виявити, охарактеризувати залежність економічної безпеки України від наявних альтернативних джерел енергії.

\section{Виклад основного матеріалу}

Безпека держави може бути досягнуто за наявності ефективного механізму управління i координації діяльності економіки, політичних сил та соціальних груп, а також дійових інститутів іiі захисту. Енергетичний комплекс $€$ однією 3 головних галузей національного господарства та забезпечує всі інші галузі енергією. Відповідно безпека держави досить тісно пов'язана 3 станом енергетичної галузі.

Л.С. Шевченко, О.А. Гриценко, С.М. Макуха зазначають, що «...економічна безпека держави (далі - ЕБД) означає захищеність усіх рівнів економіки країни від небезпечних дій, що можуть бути як наслідком свідомого впливу будь-якого чинника, так і стихійним напливом ринкових сил» [1].

Якщо розглядати економічну безпеку держави як системну категорію, то можна сказати, що головна системна вимога економічної безпеки держави полягає у забезпеченні розвитку економіки країни i, як мінімум, в утворенні передумов для іiі виживання [2, с. 127-129].

O.M. Подмазко виділив в економічній літературі вісім напрямків визначення поняття «економічна безпека» [3]: 
1. Стан економічної системи держави, що забезпечує нормальний життєвий стан населення, внутрішню стабільність і зовнішню залежність.

2. Стан економічної системи держави, що забезпечує здатність до самостійного сталого розвитку.

3. Стан економічної системи держави, що забезпечує можливість протистояти зовнішнім і внутрішнім загрозам.

4. Стан економічної системи держави, що визначається як система, модель, механізм, комплекс заходів державного регулювання економікою.
5. Стан економічної системи держави, що забезпечує сталий розвиток та добробут населення.

6. Стан економічної системи держави, що забезпечує добробут населення та здатність протистояти зовнішнім і внутрішнім загрозам.

7. Стан економічної системи держави, що забезпечує здатність протистояти загрозам та сталий розвиток.

8. Стан економічної системи держави, що забезпечує здатність протистояти загрозам, сталий розвиток та добробут населення.

Автором проаналізовані основні складові визначення поняття «економічна безпека держави» (рис. 1).

\begin{tabular}{|l|l|l|l|l|l|l|}
\hline \multicolumn{5}{|c|}{ Структрні елементи поняття «економічна безпека держави» } \\
\hline $\begin{array}{l}\text { Захищеність } \\
\text { усіх рівнів } \\
\text { економіки } \\
\text { країни }\end{array}$ & $\begin{array}{l}\text { Жормальний } \\
\text { стан }\end{array}$ & $\begin{array}{l}\text { Внутрішня } \\
\text { стабільність }\end{array}$ & $\begin{array}{l}\text { Зовнішню } \\
\text { залежність }\end{array}$ & $\begin{array}{l}\text { Комплекс } \\
\text { заходів } \\
\text { державного }\end{array}$ & $\begin{array}{l}\text { Сталий } \\
\text { розвиток }\end{array}$ & $\begin{array}{l}\text { Здатність } \\
\text { протистояти } \\
\text { зовнішнім і } \\
\text { регулювання } \\
\text { внутрішнім } \\
\text { загрозам }\end{array}$ \\
\hline
\end{tabular}

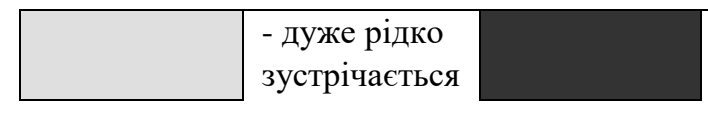

- дуже часто
зустрічається

- помірно зустрічається в визначеннях

Рис. 1. Основні складові поняття «Економічна безпека держави»

Три основні аспекти, що дуже часто зустрічається при визначенні економічної безпеки це - нормальний життєвий стан населення, сталий розвиток, здатність протистояти зовнішнім і внутрішнім загрозам.

Нормальний життєвий стан населення характеризують статистичні показники природного та механічного руху населення; зайнятості та безробіття; чисельність та зайнятість населення; індикаторів життєвого рівня та їх показники; життєвого рівня населення; матеріального забезпечення населення та домогосподарств; соціальних та демографічних показників життєвого рівня.

Здатність протистояти зовнішнім і внутрішнім загрозам характеризується такими показниками, як темпи інфляції, дефіцит державного бюджету, стабільність національної валюти, вплив зовнішньоекономічних факторів, зовнішня та внутрішня заборгованість та ін [4].

Сталий розвиток характеризується багатьма показниками. Виділяють наступні характеристики рівня сталого розвитку $[5,6]$ :

1) Екологічно-територіальні особливості просторового ландшафту, наявність природних ресурсів, стан екології тощо.

2) Економічні (Е) - економічний розвиток регіону, його виробнича структура, рівень доходів підприємств та громадян, рентабельність бізнесу, приросту ВНП тощо.

3) Політичні (П) - політична стабільність, стан законодавчої та виконавчої систем, рівень роботи судової системи, інституціональна структура регіону, інфраструктура регіону, швидкість реалізації реформ, програм, політики державного та регіонального рівня, наявність корупції в регіоні, простота ведення бізнесу, наявність пільгових умов для нього тощо.

4) Соціально-демографічні (СД) - соціальна забезпеченість громадян, рівень їх життя, природний та міграційний прирости населення.

5) Інші - рівень впровадження інновацій в регіоні, технологічний розвиток.

Загалом можна представити набір основних показників, що характеризують економічну безпеку України за всіма характеристиками (рис. 2.).

На основі перелічених характеристик, можна зазначити, що сталий розвиток $є$ однією з головних умов економічної безпеки.

В роботі для оцінки економічної безпеки автором застосовуються методичні рекомендації щодо розрахунку економічної безпеки України [7]. Згідно цих методичних рекомендацій інтегральний індекс економічної безпеки складається 39 середньозважених субіндексів (складових економічної безпеки): виробнича безпека; 
демографічна безпека; енергетична безпека; зовнішньоекономічна безпека; інвестиційноінноваційна безпека; макроекономічна безпека; продовольча безпека; соціальна безпека; фінансова безпека (банківська безпека; безпека небанківського фінансового ринку; боргова безпека; бюджетна безпека; валютна безпека; грошово-кредитна безпека).

Детальніше всі дев'ять субіндексів представлені в таблиці 1. Зауважимо, що вплив частоти використання альтернативних джерел енергії на економічну безпеку здійснюється не лише через показник енергетичної безпеки, а й через фінансову безпеку, бо як вже зазначалось дешева власна енергія є суттєвим важелем виробництва, а іiі вартість безпосередньо впливає на собівартість національної продукції.

На основі перелічених в таблиці 1 показників два рази на рік формується індекс економічної безпеки країни, що дозволяє контролювати стан економіки та попереджувати певні кризові явища.

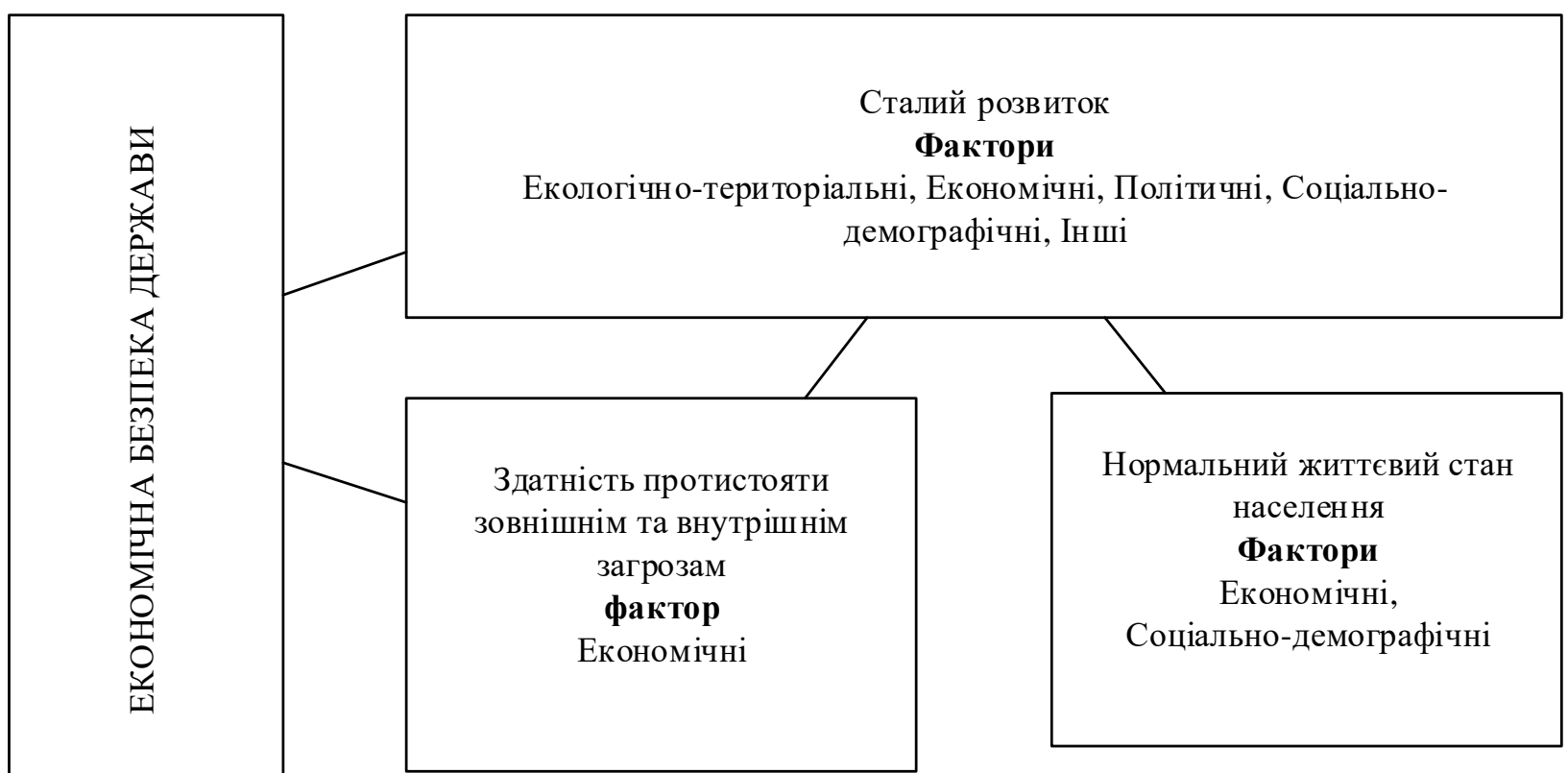

Рис. 2. Взаємозв’язок показників, що характеризують економічну безпеку держави

Таблиця 1

Детальне описання основних складових економічної безпеки держави [7]

\begin{tabular}{|l|l|}
\hline \multicolumn{1}{|c|}{$\begin{array}{c}\text { Середньозважені } \\
\text { субіндекси }\end{array}$} & \multicolumn{1}{|c|}{ Характеристика субіндексів } \\
\hline Виробнича безпека & $\begin{array}{l}\text { Стан виробничої сфери країни, за якого забезпечується максимально } \\
\text { ефективне використання наявних виробничих потужностей у країні, іх } \\
\text { модернізація та розширене відтворення, зростання рівня інноваційності } \\
\text { виробництва та підвищення рівня конкурентоспроможності національної } \\
\text { економіки }\end{array}$ \\
\hline Демографічна безпека & $\begin{array}{l}\text { Стан захищеності держави, суспільства та ринку праці від демографічних } \\
\text { загроз, за якого забезпечуєтьс розвиток України з урахуванням сукупності } \\
\text { збалансованих демографічних інтересів держави, суспільства й особистості } \\
\text { відповідно до конституційних прав громадян України }\end{array}$ \\
\hline Енергетична безпека & $\begin{array}{l}\text { Стан економіки, що сприяє ефективному використанню енергетичних } \\
\text { ресурсів країни, наявності на енергетичному ринку достатньої кількості } \\
\text { виробників та постачальників енергії, а також доступності, } \\
\text { диференційованості та екологічності енергетичних ресурсів }\end{array}$ \\
\hline $\begin{array}{l}\text { Зовнішньоекономічна } \\
\text { безпека }\end{array}$ & $\begin{array}{l}\text { Стан відповідності зовнішньоекономічної діяльності національним } \\
\text { економічним інтересам, що забезпечує мінімізацію збитків держави від дії } \\
\text { негативних зовнішніх економічних чинників та створення сприятливих } \\
\text { умов для розвитку економіки завдяки ііі активній участі у світовому } \\
\text { розподілі праці }\end{array}$ \\
\hline
\end{tabular}


Продовження табл.1

\begin{tabular}{|c|c|}
\hline $\begin{array}{l}\text { Інвестиційно-інноваційна } \\
\text { безпека }\end{array}$ & $\begin{array}{l}\text { Стан економічного середовища у державі, що стимулює вітчизняних та } \\
\text { іноземних інвесторів вкладати кошти в розширення виробництва в країні, } \\
\text { сприяє розвитку високотехнологічного виробництва, інтеграції науково- } \\
\text { дослідної та виробничої сфери } 3 \text { метою зростання ефективності, } \\
\text { поглиблення спеціалізації національної економіки на створенні продукції з } \\
\text { високою часткою доданої вартості }\end{array}$ \\
\hline Макроекономічна безпека & $\begin{array}{l}\text { Стан економіки, за якого досягається збалансованість макроекономічних } \\
\text { відтворювальних пропорцій }\end{array}$ \\
\hline Продовольча безпека & $\begin{array}{l}\text { Стан виробництва продуктів харчування в країні, що здатний повною мірою } \\
\text { забезпечити потреби кожного члена суспільства в продовольстві належної } \\
\text { якості за умови його збалансованості та доступності для кожного члена } \\
\text { суспільства }\end{array}$ \\
\hline Соціальна безпека & $\begin{array}{l}\text { Стан розвитку держави, за якого держава здатна забезпечити гідний і } \\
\text { якісний рівень життя населення незалежно від віку, статі, рівня доходів, } \\
\text { сприяти розвитку людського капіталу як найважливішої складової } \\
\text { економічного потенціалу країни }\end{array}$ \\
\hline Фінансова безпека & $\begin{array}{l}\text { Стан фінансової системи країни, за якого створюються необхідні фінансові } \\
\text { умови для стабільного соціально-економічного розвитку країни, } \\
\text { забезпечується пї стійкість до фінансових шоків та дисбалансів, } \\
\text { створюються умови для збереження цілісності та єдності фінансової } \\
\text { системи країни }\end{array}$ \\
\hline
\end{tabular}

Нажаль автор не знайшов в вільному доступі інформацію щодо інтегрального індексу економічної безпеки. Але досить багато науковців розраховували та характеризували певні індикатори, окремі сфери та складові економічної безпеки держави [1, 2, 3, 4, 5, 6, 8, 9, 10].

Автором було виділено два напрямки економічної безпеки на які безпосередньо впливає розвиток АДЕ - це фінансова безпека та енергетична безпека. Згідно методичних рекомендацій щодо розрахунку рівня економічної безпеки України питома вага загальна сума вагових коефіцієнтів цих двох складових $0,1127+0,1324=$ 0,2451 або 24,51\%, тобто чверть від усіх показників [7].

Слід зауважити, що у складової «Енергетична безпека» найвищий ваговий коефіцієнт 0,1324 . Відповідно на даному етапі розвитку нашої держави ця складова $\epsilon$ найголовнішою щодо посилення економічної безпеки України. Охарактеризуємо розвиток АДЕ в Україні та проаналізуємо вплив цієї сфери на економічну безпеку нашої держави.

1 червня 2016 року на засіданні Комітету ВРУ 3 питань ПЕК розглянуто проект Закону України про внесення змін до Закону України "Про альтернативні джерела енергії" щодо віднесення теплових насосів до обладнання, яке використовує відновлювані джерела енергії (реєстр. № 4555-1 від 23.05.2016). Законопроект розроблено у тісній співпраці 3 фахівцями Агентства 3 метою імплементації Директиви 2009/28/СС [11]. Після прийняття директиви за останні $8-10$ років спостерігається поступове зростання розвитку відновлюваних джерел енергії у світі (рис. 3).

Проаналізуємо, яке ж місце займає Україна в сфері розвитку відновлюваних джерел енергії?

Як зазначалось, енергетична безпека держави безпосередньо впливає на економічну безпеку. Останнім часом дуже гостро стає питання енергетичної незалежності держави. Україна має певні природні ресурси, на території України добувають природний газ, вугілля тощо, але великих родовищ вона не має. Відповідно стає актуальним питання пошуку додаткових джерел енергії. Для оновлення енергетичної галузі та інтенсивного її розвитку в Україні була розроблена енергетична стратегія на період до 2030 року [13].

Спочатку, відповідно стратегії, планувалося, що частка АДЕ в енергетичному балансі України може скласти 7-15\%. Але економічна криза, що супроводжувалася високою інфляцією та кризою банківського кредитування зупинило розвиток АДЕ в Україні. 3 поступовим становленням економіки відбувається відродження цієї сфери. Протягом останніх 2012-2016 років в Україні спостерігається поступове зростання встановлених потужностей альтернативних джерел енергії (АДЕ). Але цей розвиток поки що не дуже значний. Станом на кінець 2016 ріку встановлено 1117 МВт потужностей АДЕ, які виробляють близько 1\% у загальному обсязі відпущеної електроенергії. Найбільшу частку серед АДЕ в Україні займають вітрові та сонячні електростанції, на яких у 2016 році було вироблено 925 ГВт*год та 492 ГВт*год електроенергії відповідно. Що значно нижче ніж 
прийняті у Національному плані дій з відновлюваної енергетики, по досягненню $11 \%$ частки АДЕ у енергоспоживанні [14].

Станом на 1 січня 2017 року встановлена потужність об'єктів відновлюваної енергетики в Україні, які працюють за «зеленим» тарифом, склала 1117,7 МВт. У 2016 році було введено в експлуатацію 120,6 МВт потужностей, 3 них найбільше об'єктів сонячної енергетики - 99,1 МВт та вітроенергетики 11,6 МВт. Енергію з біомаси та біогазу було збудовано близько 3 МВт кожного. За даними НКРЕКП станом на кінець 2016 року галузь АДЕ в Україні налічує вже 170 компаній та 291 об'єкти енергетики. Протягом 2016 року найбільший приріст продемонструвала сонячна енергетика - 36 нових суб'єктів і 47 нових об'єктів електрогенерації. Досить серйозне зростання АДЕ відбулося і в галузі теплової енергетики (рис. 4)

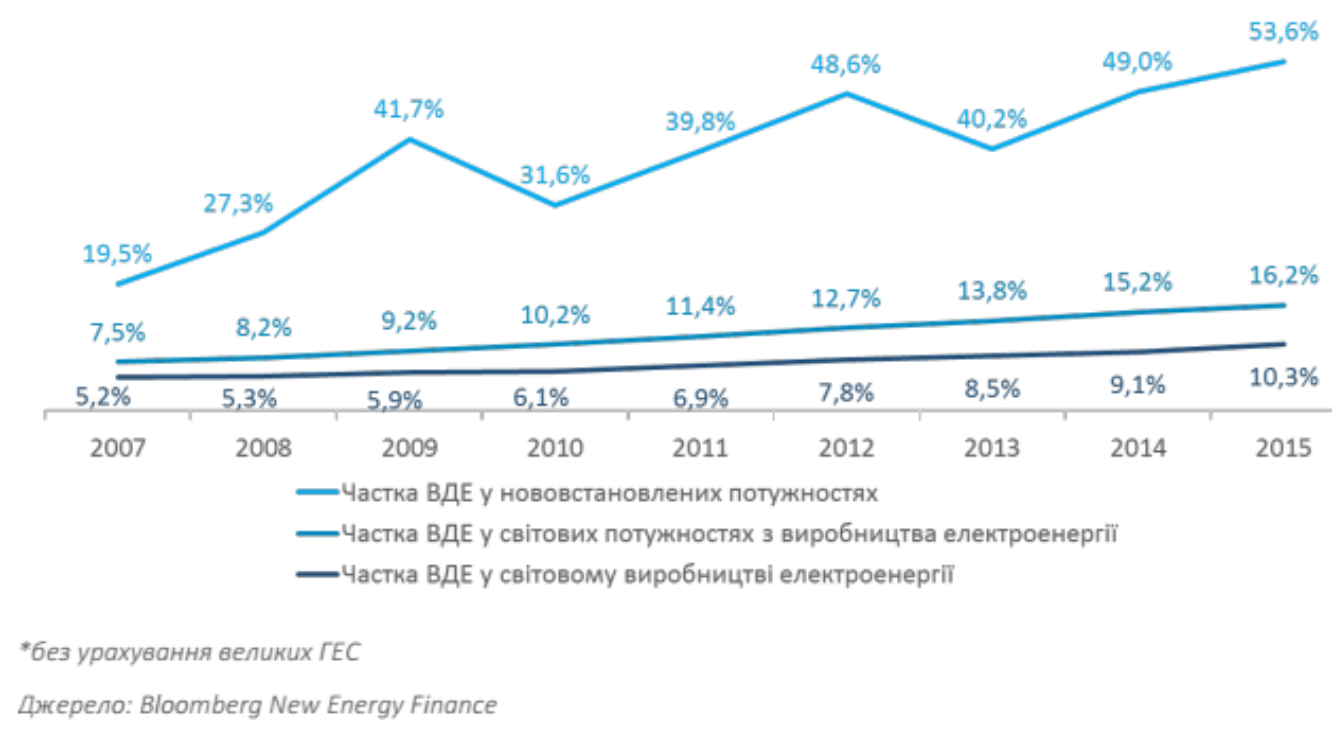

Рис. 3. Динаміка розвитку відновлюваних джерел енергії у світі [12]

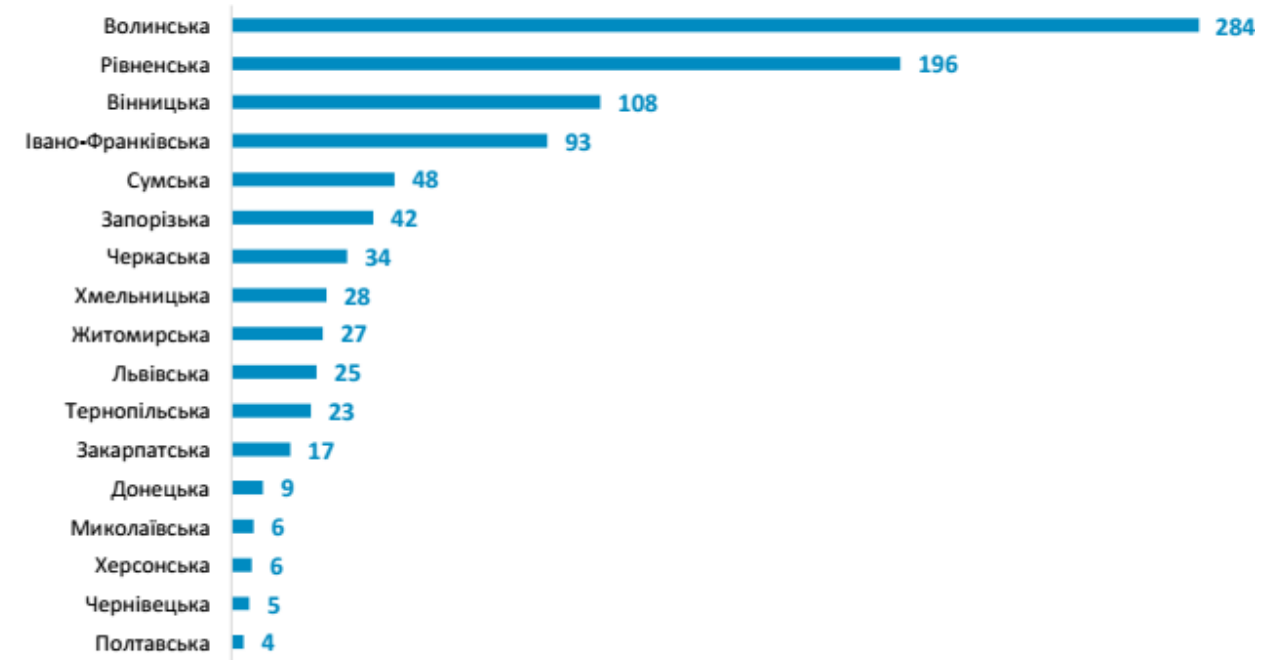

*дані по Дніпропетровській, Київській, Кіровоградській, Луганській, Одеській, Харківській, Чернігівській областям та Києву відсутні

**частина з котелень, що працює АДЕ, використовує торф, що не є відновлюваним джерелом енергії Джерело: дані UNDP «Проведення комплексного дослідження ринку котлів, що працюють на біомасі в україні»

Рис. 4. Встановлена потужність котельнь на АДЕ у 2016 році, Гкал/год [12] 
Можна зазначити, що перші кроки до впровадження АДЕ Україна вже зробила, але на цьому шляху є ще певні перепони. Нажаль, місцева влада не зацікавлена в зниженні комунальних тарифів, екологічна складова не є пріоритетом розвитку регіону. На державному рівні, як вже зазначалось, не впроваджується активних заходів щодо стимулювання впровадження АЕД. Розглянемо вплив впровадження АДЕ на економічну безпеку України (ЕБУ).
Національним інститутом стратегічних досліджень було проведено дослідження щодо стану економічної безпеки України за останні 14 років та розроблений прогноз до 2020 року [9]. Згідно цих розрахунків інтегральний коефіцієнт економічної безпеки України постійно знаходиться на пороговому рівні, періодично знижуючись та підвищуючись (рис. 5)

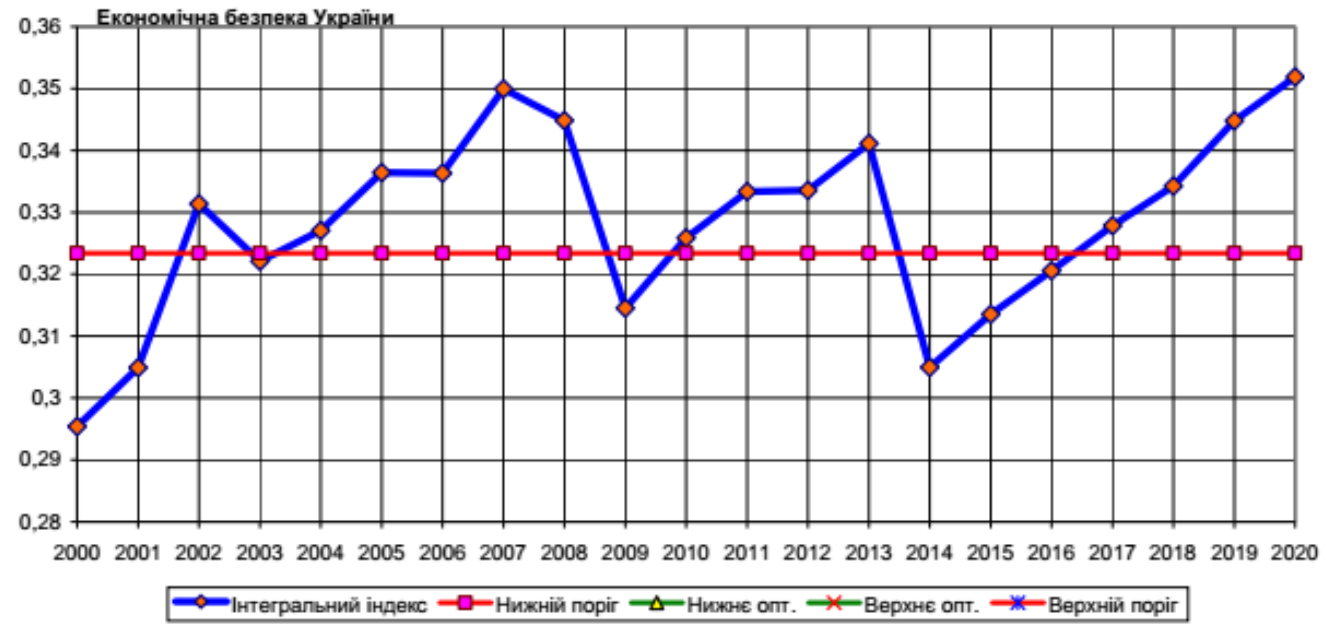

Рис. 5. Фактична та прогнозна динаміка рівня економічної безпеки України у порівнянні з нижнім пороговим значенням [9]

Розглядаючи отримані розрахункові данні можна зробити висновок, що економічна безпека України (ЕБУ) потребує додаткових заходів посилення бо за останні 15 років інтегральний коефіцієнт ЕБУ не досягав навіть оптимальних значень і майже не перевищував нижнього порогу.

Розглянемо динаміку виділених складових «Енергетичної безпеки» та «Фінансової безпеки» (рис.

$6)$.
Енергетична безпека

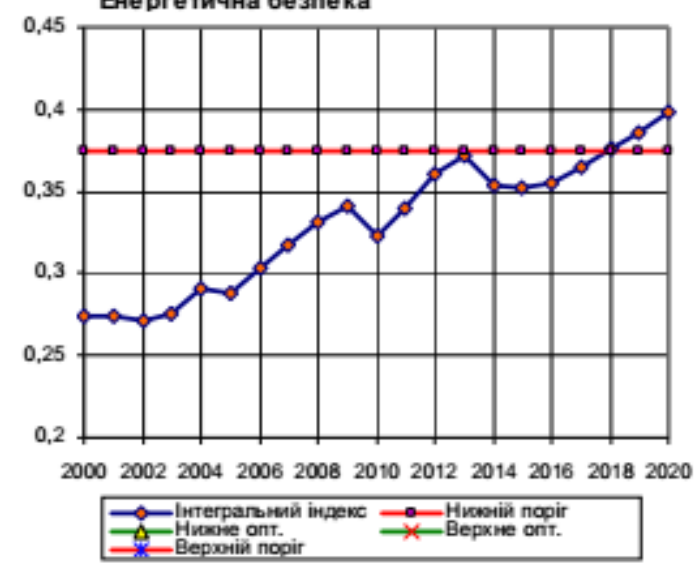

Фінансова 6езпека

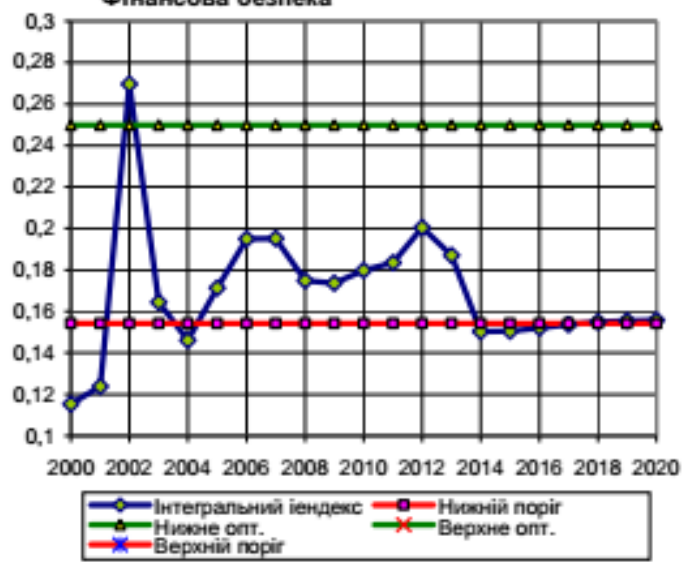

Рис. 6. Фактична та прогнозна динаміка рівня енергетичної та фінансової безпеки України у порівнянні 3 нижнім пороговим значенням [9]

На основі отриманих результатів можна заначити, що останні 15 років рівень енергетичної безпеки знаходиться нижче порогового рівня, хоча постійно збільшується. Рівень фінансової безпеки 
теж знаходиться на доволі низькому рівні, лише в 2002 році він перевищує нижній оптимальний рівень.

На основі інтегральних коефіціснтів виділених складових, що були розраховані [9] автором складена таблиця вихідних даних для виявлення залежності інтегрального коефіцієнту ЕБУ та інтегральних коефіцієнтів енергетичної та фінансової безпеки.

Між даними показниками $є$ безпосередній зв'язок, але необхідно встановити щільність зв'язку між ними та виявити розмір впливу (табл. 4). Використаємо метод кореляції.

Таблиця 4

Вихідні данні для виявлення залежності ЕБУ та основних складових

\begin{tabular}{|c|c|c|c|}
\hline Роки & $\begin{array}{c}\text { Інтегральний коефіцієнт } \\
\text { ЕБУ }\end{array}$ & $\begin{array}{c}\text { Інтегральний коефіцієнт } \\
\text { енергетичної безпеки } \\
\text { України }\end{array}$ & $\begin{array}{c}\text { Інтегральний коефіцієнт } \\
\text { фінансової безпеки } \\
\text { України }\end{array}$ \\
\hline 2000 & 0,28 & 0,27 & 0,11 \\
\hline 2001 & 0,305 & 0,27 & 0,125 \\
\hline 2002 & 0,332 & 0,27 & 0,27 \\
\hline 2003 & 0,323 & 0,28 & 0,17 \\
\hline 2004 & 0,328 & 0,29 & 0,14 \\
\hline 2005 & 0,338 & 0,287 & 0,175 \\
\hline 2006 & 0,338 & 0,3 & 0,19 \\
\hline 2007 & 0,35 & 0,32 & 0,19 \\
\hline 2008 & 0,345 & 0,335 & 0,179 \\
\hline 2009 & 0,315 & 0,34 & 0,179 \\
\hline 2010 & 0,325 & 0,325 & 0,18 \\
\hline 2011 & 0,331 & 0,345 & 0,181 \\
\hline 2012 & 0,331 & 0,36 & 0,2 \\
\hline 2013 & 0,34 & 0,375 & 0,19 \\
\hline 2014 & 0,305 & 0,36 & 0,155 \\
\hline 2015 & 0,314 & 0,355 & 0,155 \\
\hline 2016 & 0,32 & 0,36 & 0,16 \\
\hline
\end{tabular}

Кореляційний в'язок характеризується коефіцієнтом кореляції (r), який має значення в межах від 0 до +1 і від 0 до -1 . При значенні r від 0 до +1 маємо справу 3 прямою кореляційною залежністю, коли це значення від 0 до -1 залежність зворотна. Чим ближче значення коефіцієнта кореляції наближається до 1, тим тісніший (більш щільний) зв'язок між ознаками, що досліджуються.

На основі даних таблиці 4 автором виявлено залежність та побудовано рисунок 7 .

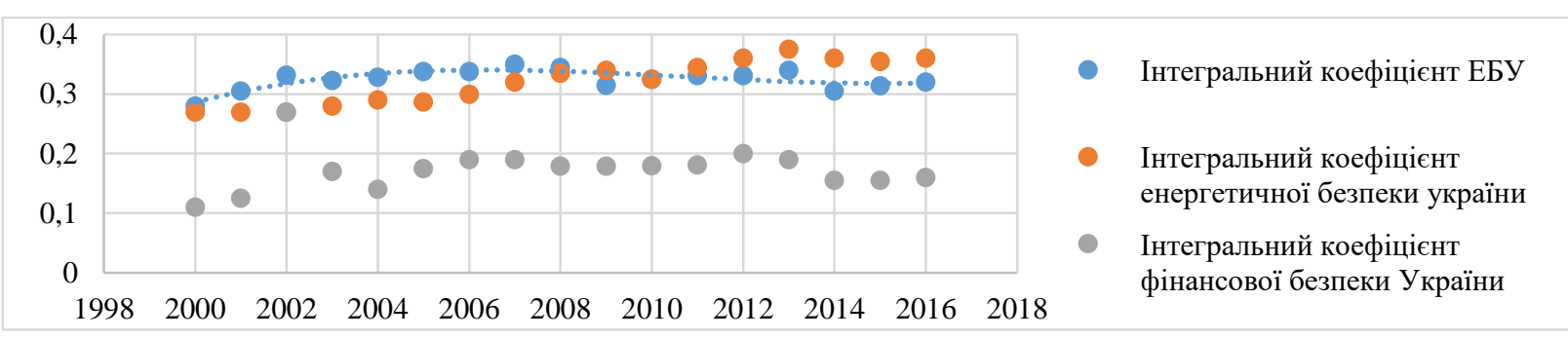

Рис. 7. Залежність ЕБУ та їі основних складових

Використовуючи інструменти програми Excel методами кореляційного та регресійного аналізу була побудована математична модель залежності, яка має вигляд: $\mathrm{Y}=0,248+0,069 * \mathrm{X}_{1}+0,313 * \mathrm{X}_{2}$. Зв'язок між переліченими факторами присутній. Можна зазначити, що модель в цілому статистично 
значима, відсутня мультиколініарність (залежність між $\mathrm{X}_{1}$ та $\mathrm{X}_{2}$ дорівнює 0,097), досить високий вплив на результативний показник $(\mathrm{R}=0,64)$ має $\mathrm{X}_{2}-$ фінансова безпека, помірний $(\mathrm{R}=0,21) \mathrm{X}_{1}-$ енергетична безпека. Загальний $\mathrm{R}=0,66, \mathrm{R}^{2}=0,45$, стандартна помилка $1,3 \%$.

Розробимо математичну модель прогнозування ЕБУ в залежності від розвитку ВЕД використовуючи дані табл. 5 .

Таблиця 5

Вихідні данні для виявлення залежності ЕБУ та розвитку АДЕ $[9,12,14]$

\begin{tabular}{|c|c|c|c|c|c|c|}
\hline Роки & $\begin{array}{c}\text { Інтегральний } \\
\text { коефіцієнт ЕБУ }\end{array}$ & $\begin{array}{c}\text { Темпи росту } \\
\text { інтегрального } \\
\text { коефіцієнта } \\
\text { ЕБУ (Y) }\end{array}$ & $\begin{array}{c}\text { Потужності } \\
\text { електроенергії, } \\
\text { що виробляють } \\
\text { ВДЕ, МВт }\end{array}$ & $\begin{array}{c}\text { Цепні темпи } \\
\text { росту } \\
\text { потужності } \\
\text { електроенергї } \\
\text { ВДЕ }\left(\mathrm{X}_{1}\right) \\
\end{array}$ & $\begin{array}{c}\text { Об'єкти } \\
\text { ВДЕ, } \\
\text { шт. }\end{array}$ & $\begin{array}{c}\text { Цепні } \\
\text { темпи } \\
\text { росту } \\
\text { об'єктів } \\
\text { ВДЕ }\left(\mathrm{X}_{1}\right)\end{array}$ \\
\hline 2009 & 0,315 & 1,000 & 126 & 1 & 89 & 1 \\
\hline 2010 & 0,325 & 1,032 & 146 & 1,159 & 94 & 1,056 \\
\hline 2011 & 0,331 & 1,018 & 410 & 2,808 & 103 & 1,096 \\
\hline 2012 & 0,331 & 1,000 & 645 & 1,573 & 138 & 1,340 \\
\hline 2013 & 0,34 & 1,027 & 1187 & 1,840 & 199 & 1,442 \\
\hline 2014 & 0,305 & 0,897 & 967 & 0,815 & 199 & 1,000 \\
\hline 2015 & 0,314 & 1,030 & 1001 & 1,035 & 227 & 1,141 \\
\hline 2016 & 0,32 & 1,019 & 1118 & 1,117 & 291 & 1,282 \\
\hline
\end{tabular}

Використовуючи інструменти програми Excel методами кореляційного та регресійного аналізу була побудована математична модель залежності, яка має вигляд: $\mathrm{Y}=0,872+0,018 * \mathrm{X}_{1}+0,089 * \mathrm{X}_{2}$.

Зв'язок між переліченими факторами присутній. Можна зазначити, що модель в цілому статистично значима, але присутня невисока мультиколініарність (залежність між $\mathrm{X}_{1}$ та $\mathrm{X}_{2}$ дорівнює 0,29), не досить високий вплив на результативний показник $(\mathrm{R}=0,36)$ має $\mathrm{X}_{1}-$ цепні темпи росту потужності електроенергії ВДЕ, помірний $(\mathrm{R}=0,41) \mathrm{X}_{2}$ - цепні темпи росту об'єктів ВДЕ. Загальний $\mathrm{R}=0,48, \mathrm{R}^{2}=0,23$, стандартна помилка 4,6\%.

Використовуючи інструменти програми Excel методами кореляційного та регресійного аналізу була побудована математична модель залежності, яка має вигляд: $\mathrm{Y}=0,872+0,018 * \mathrm{X}_{1}+0,089 * \mathrm{X}_{2}$. Зв'язок між переліченими факторами присутній. Можна зазначити, що модель в цілому статистично значима, але присутня невисока мультиколініарність (залежність між $\mathrm{X}_{1}$ та $\mathrm{X}_{2}$ дорівнює 0,29), не досить високий вплив на результативний показник $(\mathrm{R}=$ 0,36) має $\mathrm{X}_{1}$ - цепні темпи росту потужності електроенергії ВДЕ, помірний $(\mathrm{R}=0,41) \mathrm{X}_{2}$ - цепні темпи росту об'єктів ВДЕ. Загальний $\mathrm{R}=0,48, \mathrm{R}^{2}=$ 0,23, стандартна помилка 4,6\%.

Результати проведеного кореляційного аналізу (табл. 6) говорять про те, що розвиток ВДЕ опосередковано впливає на економічну безпеку України і параметри моделі мають помірний зв'язок.

Таблиця 6

Результати проведеного аналізу

\begin{tabular}{|l|l|l|}
\hline Математична модель & Параметри моделі & $\begin{array}{l}\text { Щільність зв'язку та сила впливу } \\
\text { факторів на результативний } \\
\text { показник }\end{array}$ \\
\hline $\mathrm{y}=0,248+0,069^{*} \mathrm{X}_{1}+0,313^{*} \mathrm{X}_{2}$. & $\begin{array}{l}\text { Множинна } \mathrm{R} 0,66 \\
\text { R-квадрат } 0,43 \\
\text { Стандартна помилка } 0,014\end{array}$ & $\begin{array}{l}\text { Щільність впливу досить висока } \\
(0,66), \text { фінансова безпека впливає } \\
\text { більше ніженергетична безпека. }\end{array}$ \\
\hline $\mathrm{y}=0,872+0,018^{*} \mathrm{X}_{1}+0,089 * \mathrm{X}_{2}$ & $\begin{array}{l}\text { Множинна } \mathrm{R} 0,48 \\
\text { R-квадрат 0,23 } \\
\text { Стандартна помилка } 0,046\end{array}$ & $\begin{array}{l}\text { Щільність впливу помірна }(0,48), \\
\text { цепні темпи росту потужності та } \\
\text { об'єктів ВДЕ помірно впливають } \\
\text { на темп росту інтегрального } \\
\text { iндексу ЕБУ }\end{array}$ \\
\hline
\end{tabular}


На думку автора щільність зв'язку цепних темпів росту потужності електроенергії ВДЕ, цепних темпів росту об'єктів ВДЕ та інтегральних коефіцієнту ЕБУ говорить про важливість впровадження альтернативних джерел енергії. Розглянемо наскільки перелічені показники вплинуть на економічну безпеку країни в прогнозному періоді (табл. 7).

Таблиця 7

Прогнозні показники впливу на темпи росту інтегрального коефіцієнту ЕБУ

\begin{tabular}{|c|c|l|c|}
\hline $\begin{array}{l}\text { Прогнозні } \\
\text { роки }\end{array}$ & $\begin{array}{l}\text { Tемпи росту інтегрального } \\
\text { коефіцієнту ЕБУ }\end{array}$ & $\begin{array}{l}\text { Цепні темпи росту } \\
\text { потужності електроенергії } \\
\text { ВДЕ }\end{array}$ & $\begin{array}{l}\text { Цепні темпи росту цепні } \\
\text { темпи росту об'єктів ВДЕ }\end{array}$ \\
\hline 2017 & 1,00168 & 1,37 & 1,18 \\
\hline 2018 & 1,01238 & 1,47 & 1,28 \\
\hline 2019 & 1,02308 & 1,57 & 1,38 \\
\hline
\end{tabular}

Стале збільшення темпів росту факторних показників дозволить збільшити результативний показник на 2,3\%. 3 урахуванням помилки в 4,6\% можна зазначити, що інтервал темпів росту в 2019 році складе $2,1-2,4 \%$.
Розглянемо наскільки посилення енергетичної та фінансової безпеки посилить економічну безпеку країни (табл. 8).

Прогнозні показники впливу на розмір інтегрального коефіцієнту ЕБУ

Таблиця 8

\begin{tabular}{|c|c|c|c|}
\hline & & & \\
& Рнтегральний коефіцієнт \\
ЕБУ & $\begin{array}{c}\text { Інтегральний коефіцієнт } \\
\text { енергетичної безпеки } \\
\text { України }\end{array}$ & $\begin{array}{c}\text { Інтегральний коефіцієнт } \\
\text { фінансової безпеки України }\end{array}$ \\
\hline 2017 & 0,33751 & 0,39 & 0,2 \\
\hline 2018 & 0,34446 & 0,4 & 0,22 \\
\hline 2019 & 0,34828 & 0,41 & 0,23 \\
\hline
\end{tabular}

Стале збільшення енергетичної та фінансової безпеки посилить економічну безпеку країни до 0,35. 3 урахуванням помилки в $1,3 \%$ можна зазначити, що інтервал результативного показника в 2019 році складе $0,32-0,37 \%$.

Слід зазначити, що нижнє порогове значення складає 0,325, відповідно 3 постійним збільшенням інтегральних коефіцієнтів енергетичної та фінансової безпеки інтегральний коефіцієнт ЕБУ буде знаходитися вище порогового значення.

\section{Висновки досліджень}

На основі проведених досліджень стає зрозумілим, що зв'язок між ЕБУ та впровадженням АДЕ досить тісний. Розроблені моделі в цілому статистично значимі, але присутня невисока мультиколініарність в другій моделі, відповідно моделі в подальшому будуть скореговані, розширені факторами та ще раз перевірені за критеріями Фішера та Дарвіна-Вотса.

\section{Література}

1. Економічна безпека держави: сутність та напрями формування [Текст]: монографія / Л. С. Шевченко, О. А. Гриченко, С. М. Макуха та ін. / за ред. д-ра екон. наук, проф. Л. С. Шевченко. - Х.: Право, 2009. - 312 с.

2. Экономическая и национальная безопасность [Текст] : учеб. / под ред. Е. А. Олейникова. - М. : Экзамен, 2004. $768 \mathrm{c}$.

3. Подмазко, О.М. Начіональна економічна безпека: аналіз основних підходів [Текст] / О.М. Подмазко; під ред. А. С. Василь'єв [голова] (та ін.) // Ринкова економіка: сучасна теорія і практика управління. T. 1, вип. 2/2 : наук. прачіО. : Наука і техніка, 2014. -228 c.

4. Хаванов, А.В. Критерї та показники економічної безпеки в умовах державної заборгованості та їх вплив на економіку України [Текст] / А.В. Хаванов // Бюлетень Міжнародного Нобелівського економічного форуму.2012. - № 1 (5). - Том 2 - C.374-382

5. Регіональні асиметрії сталого розвитку України: діагностика та механізми вирівнювання [Текст]: монографія / I.М. Вахович, О.С. Табалова - Луц̧ьк «Волиньполіграф» ТМ, $2012-343 c$. 
6. Смачило, В.В. Оиінювання демографічної безпеки [Текст] / В.В. Смачило, О.М. Колмакова // Сучасні проблеми і перспективи розвитку підприємств України: Колективна монографія / За заг. ред. д-ра екон. наук, проф. О.С. Іванілова - Харків.: ФОП Панов А. М., Видав. дім «В справі», 2015. - с.305-312.

7. Методичні рекомендації щзодо розрахунку рівня економічної безпеки Украйни [Електронний ресурс] Режим доступy: http://www.me.gov.ua/Documents $/$ List lang $=u k-U A \&$ tag $=$ MetodichniRekomendatsii

8. Буркальцева, Д. Д. Методологія розрахунку інтегральних показників безпеки за сферами економіки [Текст] / Д. Д. Буркальцева // Збірник наукових працьь Дніпропетровського національного університету залізничного транспорту імені академіка В. Лазаряна «Проблеми економіки транспорту» - 2013. - Bun. 6. - C. $106-111$

9. Прогнозування індикаторів, порогових значень та рівня економічної безпеки Украӥни у середньостроковіи перспективі; аналіт. доп . [Текст] / Ю.М. Харазішвілі, С.В. Дронь. - К.: НІСД, 2014. -117 c.

10. Оиінка стану енергетичної безпеки України: методологічні підходи, критерії, індикатори [Текст] / Воронциов С. Б., Сидоренко А. А., Сменковський А. Ю. //Стратегічні пріоритети, №2 (23). - 2012 p. - С. 22-30

11. ДИРЕКТИВА СВРОПЕЙСЬКОГО ПАРЛАМЕНТУ ТА РАДИ 2009/28/СС від 23 квітня 2009 року про заохочення до використання енергії, виробленої з відновлюваних джерел та якою вносяться зміни до, а в подальшому скасовуються Директиви 2001/77/СС та 2003/30/СС (Текст має значення для СЕП) [Електронний ресурс] // Офіційний вісник Європейського Союзу від 05.06.2009 року-C.16-62. - Режим доступу:

http://saee.gov.ua/documents/dyrektyva_2009_28.pdf

12. Розвиток відновлюваних джерел енергії в Украйні [Електронний ресурс] // Звіт підготовлено в рамках проекту «Секретаріат та Експертний хаб з енергоефективності», щзо впроваджується Програмою розвитку ООН в Украӥні за підтримки Уряду Республіки Словакія та сприяння Міністерства регіонального розвитку, будівництва та житлово-комунального господарств в Україні 2017p. - Режим доступу: http://abc.in.ua/wp-content/uploads/2017/03/Rozvitok-VDE-vUkrai-ni.pdf

13. Енергетична стратегія України на період до 2030 року [Електронний ресурс]. - Режим доступу:

zakon.rada.gov.ua/signal/kr06145a.doc

14. Альтернативна енергетика Украӥни: сонце, вітер $i$

вода [Електронний ресурс]. - Режим доступу:

https://news.finance.ua/ua/news/-/353701/alternatyvna-

energetyka-ukrayiny-sontse-viter-i-voda

\section{References}

1. Shevchenko, L. S., Gritsenko, O. A., Makukha, S. M. and others. (2009) Economic security of the state: the essence and directions of formation. Monograph - 312

2. Oleynikova, E. A. (2004) Economic and national security. Study - 768

3. Podmazko, O.M. (2014) National Economic Security: An Analysis of Main Approaches. Market Economy: Modern Theory and Practice of Management. - 228
4. Havanov, A.V. (2012) Criteria and indicators of economic security in the conditions of public debt and their impact on the Ukrainian economy. Bulletin of the International Nobel Economic Forum, 1 (5), 374-382

5. Vakhovich, I.M., Tabalova, O.E. (2012) Regional asymmetries of sustainable development of Ukraine: diagnostics and alignment mechanisms. Monograph - Lutsk Volyn Polygraph TM, 343

6. Smachilo, V.V., Kolmakova, O.M. (2015) Demographic Security Assessment. Modern problems and perspectives of the development of Ukrainian enterprises: Collective monograph. 305-312.

7. Methodical recommendations for calculating the level of economic security of Ukraine / Order of the Ministry of Economic Development and Trade of Ukraine dated October 29, 2013 № 1277 - Retrieved from

http://www.me.gov.ua/Documents/List? Lang = uk-UA \& tag = MetodichniRecomendatsii

8. Burkaltseva, D. D. (2013) Methodology of calculation of integral indicators of security in the spheres of economy Collection of scientific works of Dnipropetrovsk National University of Railway Transport named after academician V. Lazaryan "Problems of Transport Economics". Proceedings. 6, $106-111$

9. Kharazishvili, U.M., Drown, E.V. (2014) Forecasting of indicators, threshold values and level of economic security of Ukraine in the medium-term perspective. Analyte additional, 117

10. Vorontsov, S.B., Sidorenko, A.A., Smenkovsky, A. Yu. (2012) Assessment of the state of energy security in Ukraine: methodological approaches, criteria, indicators. Strategic Priorities, No. 2 (23), 22-30

11. DIRECTIVE 2009/28 / EC OF THE EUROPEAN PARLIAMENT AND OF THE COUNCIL 2009/28/EU of 23 April 2009 on the promotion of energy produced from renewable sources, amending and subsequently repealing Directives 2001/77 / EU and 2003/30 / EU // Official Journal of the European Union dated 06/05/2009, 16-62 Retrieved from

http://saee.gov.ua/documents/dyrektyva_2009_28.pdf

12. The development of renewable energy in Ukraine // report was prepared under the "Expert hub Secretariat and energy efficiency", implemented by UNDP in Ukraine with the support of the Government of the Republic of Slovakia and the support of the Ministry of Regional Development, Construction and Housing and Communal Services of Ukraine 2017. Retrieved from

http://abc.in.ua/wp-content/uploads/2017/03/Rozvitok-VDEv-Ukrai-ni.pdf

13. Energy strategy of Ukraine for the term up to 2030. Retrieved from

zakon.rada.gov.ua/signal $/ \mathrm{kr} 06145 \mathrm{a} . \mathrm{doc}$

14. Alternative energy of Ukraine: the sun, wind and water. Retrieved from

https://news.finance.ua/ua/news/-/353701/alternatyvnaenergetyka-ukrayiny-sontse-viter-i-voda

Рецензент: доктор економічних наук професор О.М. Чупир, Харківський національний університет будівництва та архітектури, Харків, Україна 
Автор: КОЛМАКОВА Олена Миколаївна

кандидат економічних наук, доцент, доцент

кафедри економіки

Харківський національний університет будівницутва

та архітектури

E-mail-elenkolmakova78@gmail.com

ID ORCID: http://orcid.org/0000-0003-0908-5445

\section{ECONOMIC SECURITY OF UKRAINE: ENERGY ASPECTS}

O. Kolmakova

Kharkiv National University of Construction and Architecture, Ukraine

Protection the surrounding the environment may be beneficial from an economic point of view. Economic effects from implementation alternative and renewable sources energy not always you can determine by direct calculation. The cost of each product and service includes the cost of energy. Accordingly, the energy policy of the state directly affects the socio-economic state of Ukraine. This confirms the relevance of the research topic.

State security can be achieved by having an effective mechanism for managing and coordinating the activities of the economy, political forces and social groups, as well as effective institutions for its protection. The energy complex is one of the main sectors of the national economy and provides all other sectors with energy. Accordingly, the security of the state is quite closely connected with the state of the energy industry.

It can be noted that Ukraine has already made the first steps towards the introduction of alternative energy sources, but there are still some obstacles on this path. Unfortunately, the local authorities are not interested in reducing utility tariffs, the environmental component is not a priority for the region's development. At the state level, there are no active measures to stimulate the introduction of alternative energy sources.

The National Institute for Strategic Studies conducted a study on the state of economic security of Ukraine over the past 14 years and a forecast for 2020. According to these calculations, the integral coefficient of Ukraine's economic security is constantly at the threshold level, periodically decreasing and rising. Considering the estimated data obtained, we can conclude that the economic security of Ukraine require additional measures for strengthening the integral factor of economic securityand Ukraine have not even reached the optimum values almost does not exceed the lower threshold.

That is why, and the second was a detailed analysis of the main components of the concept "Economic security of the state". The study tracks the relationship of indicators characterizing the economic security of the state, gives a detailed description of the main components of economic security of the state, analyzes the dynamics of the development of renewable energy sources in the world. As a result of the study of the interconnection of the implementation of alternative energy sources and energy security of Ukraine, the feasibility of their implementation has been proved. Regression models have been obtained to predict the relationship between economic security and financial, energy components. On the basis of the conducted research, it becomes clear that the link between Ukraine's economic security and the implementation of alternative energy sources is rather tight. Generally, models are generally statistically significant, but the presence of low multicollinearity, respectively, will be further corrected, expanded by factors and checked again according to the Fisher and Darwin-Watts criteria. As a result of their application, the author received a forecast of the level of economic security in Ukraine, proving: with the constant increase of the integral coefficients of energy and financial security, the integral coefficient of economic security of Ukraine will be above the threshold.

Keywords: economic security, energy security, alternative energy sources, forecasting. 